\title{
Pakistan eyeing collaborating with Delhi, Kabul over water management
}

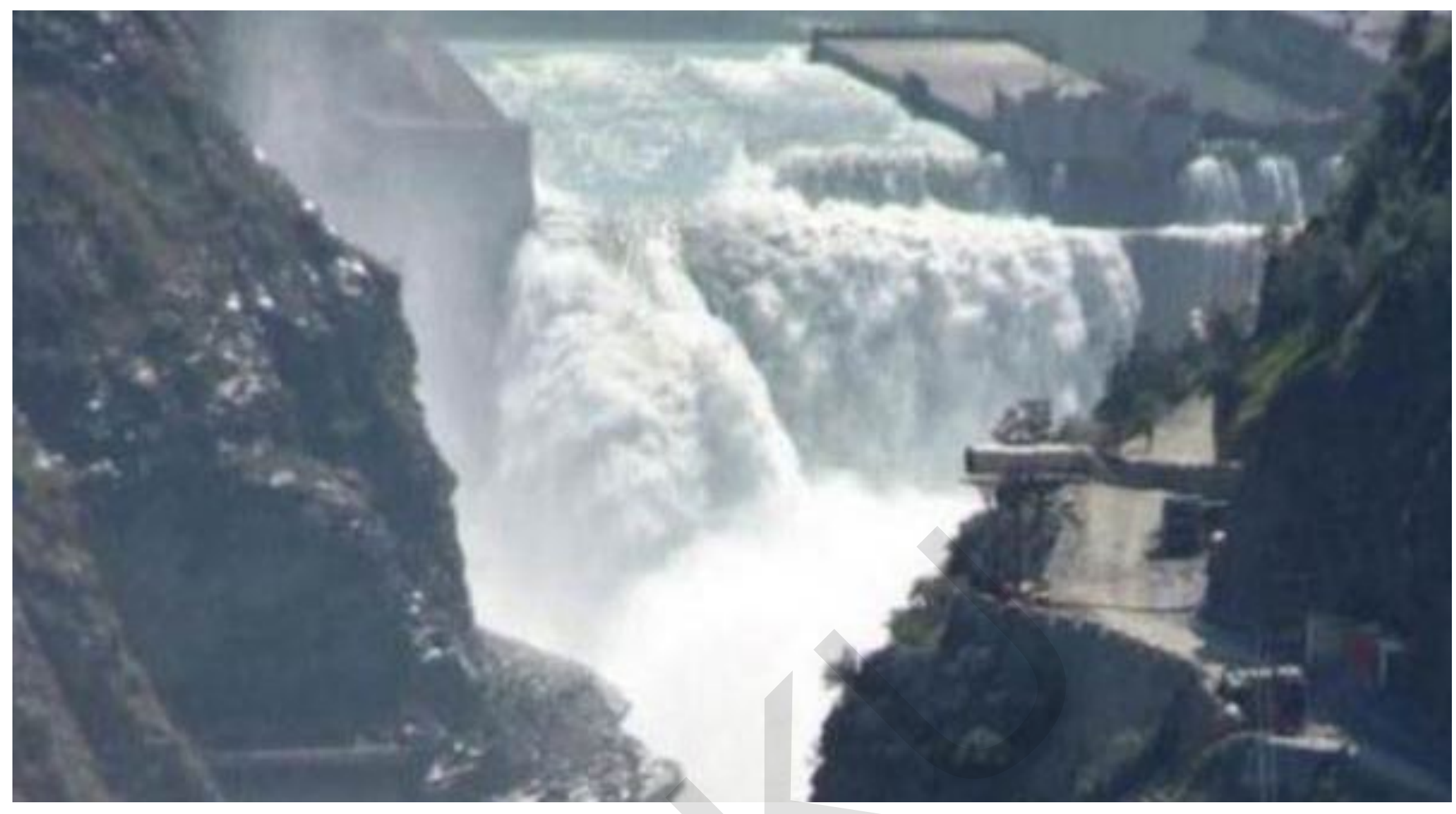

Lahore: At a time when tensions between India and Pakistan are at an all time high, Islamabad is planning to hold joint mechanism with India and Afghanistan for joint watershed management and trans-boundary aquifer sharing, to minimize the negative impact of development projects.

A study would also be conducted to analyze the impact of the challenges arising out of the developments on western rivers and minimize the effect within the framework of the Indus Waters Treaty and International water laws.

The watershed management is part of the National Water Policy that seeks to improve the water quality, while aquifer refers to the underground layer of rock or minerals that holds water.

The National Water Policy also seeks to ensure 10opc metering of urban water uses, including drinking and sanitation, The policy concedes that the Indus water Treaty provided a mechanism for water-sharing with India but its provisions on hydropower development across the line of control had the potential of threatening Pakistan's water availability during low-flow 
periods. reports Dawn.

Policy stated that when two neighbours are involved regional mechanisms should be explored for a viable solution to Pakistan's growing vulnerability to hydrometer logical disasters, owing to trans-border winter releases and stoppages during monsoon season.

Indian Prime Minister Narendra Modi had held a meeting in September 2016 to review the Indus water treaty after the terror strikes in Uri declaring that "blood and water cannot flow together".

Indian government, thus decided to increase the utilization of rivers flowing through Jammu and Kashmir to fully exercise India's rights as per the Indus Waters Treaty .

The 1960 treaty grants control of the eastern rivers- Sutlej,Beas and Ravi rivers to India while the western rivers- Indus, Jhelum and Chenab to Pakistan.

$-\mathrm{ANI}$ 